\title{
La capilla madrileña de San Isidro y sus proyectos previos
}

\author{
Juan María CRUZ YÁBAR \\ Conservador del Museo Arqueológico Nacional \\ juan.cruz@mecd.es
}

Recibido: 27-02-2015

Aceptado: 12-09-2015

\section{RESUMEN}

Desde antiguo ha examinado la historiografía la documentación relativa a la capilla de San Isidro en Madrid, deteniéndose en algunos proyectos que quedaron sin realizar hasta el definitivo de 1657. Sin embargo, esos intentos anteriores no han sido reseñados en su totalidad ni de manera correcta y exhaustiva. En este trabajo damos a conocer nuevos proyectos y precisamos muchos aspectos de los conocidos.

Palabras clave: Iglesia parroquial de San Andrés de Madrid. Capilla de San Isidro. Don Juan de Tapia. Juan Gómez de Mora. Alonso Carbonel. Pedro de la Torre.

\section{The Madrilenian Chapel of San Isidro and its Previous Proyects}

\begin{abstract}
Since a long time ago, historiography has examined the documentation relating to San Isidro chapel in Madrid, wasting time on some plans which were not made until the definitive from 1657. However, those previous attempts have not seen totally reviewed or correct and exhaustive way. In this piece of work we announce new plans and specify many aspects of those known.
\end{abstract}

Key Words: Parish Church of San Andrés in Madrid. San Isidro chapel. Don Juan de Tapia. Juan Gómez de Mora. Alonso Carbonel. Pedro de la Torre.

Sumario: 1. El primer plan para una capilla de San Isidro de Juan Gómez de Mora (1629). 2. Gómez de Mora y su reforma de la capilla mayor de la iglesia parroquial de San Andrés (hacia 1636). 3. El primer concurso para capilla ganado por Alonso Carbonel (1638). 4. Pedro de la Torre vencedor del segundo concurso, de iglesia de San Andrés y capilla del Santo (1642). 5. El triunfo de Gómez de Mora en el tercer concurso para capilla (1643). 
La beatificación en 1620 y la canonización en 1622 de San Isidro, patrón de la villa de Madrid, fueron festejadas con grandes actos y decoraciones efímeras, y los plateros madrileños ofrecieron el 15 de mayo del primer año, festividad del Santo, una urna de plata para albergar su sarcófago, labrada por Diego de Zabalza ${ }^{1}$. En los años siguientes, tanto el Concejo madrileño como el Consejo real trataron de edificarle un espacio arquitectónico que diera lustre al culto de la reliquia. Fueron varios los proyectos que se sucedieron, al menos cinco entre 1629 y 1643, con diversas soluciones, antes de que se llevara a buen término la capilla adosada a la iglesia de San Andrés, edificada entre 1657 y 1669 . Tres de los proyectos que denominamos fallidos dieron lugar a concursos entre los más prestigiosos arquitectos del Madrid del momento.

Antes de ocuparnos de los proyectos concretos parece conveniente exponer la situación de la iglesia de San Andrés y su entorno, el principal inconveniente para la creación de un espacio dedicado a San Isidro que reuniera las condiciones de dignidad deseadas. La nave de la iglesia estaba orientada de oeste a este, donde se situaba su cabecera, y estaba rodeada de edificaciones de particulares. La descripción que realiza el regidor don Juan de Cuero y Tapia, comisionado por el Concejo en 18 de junio de 1641 para explorar las posibilidades al respecto es magistral, y optamos por transcribir textualmente algunos de sus párrafos:

"En la junta del martes diez y ocho deste mes de junio del año de 641 se me encomendó poner en escrito mi conferencia para resolver sobre la translación del cuerpo del glorioso San Ysidro, que tan continuamente por tanto tiempo se a procurado, a que se an opuesto las dificultades siguientes:

La yglesia parroquial de San Andrés tiene por el largo y delantera el cimenterio y calle pública que están al mediodía, por los pies al poniente la callejuela del pasadizo de las casas del duque del Infantado, por el otro largo al setentrión el patronazgo de la capilla del obispo don Gutierre de Caravajal, y por el Oriente detrás del altar mayor las casas del mayorazgo que posee don Fadrique Enrríquez por hijo de doña Catalina de Luxán..."2.

El regidor sigue dando cuenta de las dificultades, y relata los inconvenientes de trazar nada que invadiera las casas situadas al este,

"Haviendo de edificarse capilla en los términos linderos de la mayor, embaraza la del obispo, que su edificio cay al lado del evanjelio, de cuya pared aún no se puede ocupar el gruesso para arco y altar emvevido, por tener en el reverso el epitafio del dicho obispo muy costoso y ser lustre blasón y memoria de aquel patronazgo que posse al presente don Fadrique de Vargas...".

La única parte asequible para la expansión era el mediodía, donde se abría la única puerta del templo que salía a la calle pública. Todos los proyectos fallidos que abor-

1 CRUZ VALDOVINOS, José Manuel, Los plateros madrileños. Estudio histórico-jurídico de su organización corporativa, Madrid, 1983, pp. 381-389.

2 Vid. nota 13. 
daron la edificación de una capilla del santo madrileño utilizaron ese espacio, pero las propuestas fueron diferentes, como veremos a continuación.

\section{El primer plan para una capilla de San Isidro de Juan Gómez de Mora (1629)}

A pesar de algunas tentativas de la Villa documentadas desde $1620^{3}$, las primeras noticias seguras en torno a un proyecto de capilla datan del 15 de diciembre de 1629 . Tovar $^{4}$ transcribió de forma parcial y comentó sucintamente unas condiciones firmadas por Pedro de Pedrosa en dicha fecha en que se hacía referencia a una traza. La estudiosa creyó reconocerla en un dibujo perteneciente al Archivo de Villa ${ }^{5}$, fechado diez años después y con una leyenda firmada por Juan Gómez de Mora, que habilitaba la capilla en la nave lateral de la iglesia de San Andrés. Demostraremos que el dibujo nada tiene que ver con las condiciones de Pedrosa, sino que es copia de un proyecto posterior de Alonso Carbonel.

Para poder interpretar estas condiciones de Pedrosa es necesario consultar la planta de la iglesia parroquial de San Andrés trazada por Gómez de Mora en 1626 ${ }^{6}$. Una transcripción completa y una lectura pausada de las condiciones de Pedrosa nos llevan a conclusiones que difieren bastante de lo que hasta ahora se había dicho sobre este asunto. Lo que se establece en ellas es el derribo de un pedazo de la pared de la epístola de la iglesia, el situado entre la que en 1626 se denominaba "puerta a la plaçuela" y el comienzo de la capilla de los Ugartes en la cabecera del templo. La nueva capilla se concibió como una edificación añadida a la nave lateral de la iglesia, orientada en el mismo sentido que lo estaba la nave principal. Se detalló con cuidado la forma en que se haría la cimentación del nuevo espacio, con zanjas profundas de quince pies, bien macizadas, incluida la parte de la sacristía.

Se accedía a la capilla por los pies, que contaban con una portada al exterior en ángulo con la puerta de San Andrés a la plazuela; se abría una segunda puerta cuya situación, no muy explícita en el documento, parece que podía comunicar la capilla con la nave lateral de la iglesia. En el interior tenía un primer cuerpo cuadrado, cuyo

3 Prueba de ese interés está en las afirmaciones de don Gabriel de Ugarte, quien poseía una capilla familiar junto a la cabecera de la parroquial de San Andrés, en el lado de la epístola, en un poder dado en la ciudad de México en 1637, en que decía que pasó a Nueva España catorce años antes, y que hasta ese momento el cabildo y regidores de Madrid habían tratado de convencerle para que cediera la propiedad de la capilla para poder hacer más amplia la del Santo (vid nota 33).

4 Archivo de Villa (A.V.), Archivo de Secretaría del Ayuntamiento (A.S.A.), 1-66-71. TOVAR MARTÍN, Virginia, Arquitectura madrileña del s. XVII, Madrid, Instituto de Estudios Madrileños, 1983, pp. 277282 y 741; y EADEM, Juan Gómez de Mora (1586-1648), Madrid, Ayuntamiento, 1986, p. 247. Faltan en la transcripción cinco de las condiciones, entre ellas las tres primeras, y las otras veintiséis presentan lagunas que impiden su correcta comprensión.

5 EADEM. Citado por primera vez en EADEM, Arquitectos madrileños de la segunda mitad del siglo XVII, Madrid, Instituto de Estudios Madrileños, 1975, pp. 131-132. A.V., Planos, Sig. 59-31-40. Tinta y aguada roja, 770 x $484 \mathrm{~mm}$. Actualmente está depositado en el Museo de Historia de Madrid.

6 Esta planta de 1626 fue hecha con ocasión del bautismo de la infanta María Eugenia, que tuvo lugar el 7 de junio (Biblioteca de Palacio Real, TOVAR, Juan Gómez de Mora..., op. cit., p. 251) y en el plano de Texeira de 1656, anterior a la capilla definitiva. 
alzado se componía de zócalo o embasamento en mármol serpentino de los montes de Toledo con grandes placas de tres pies, de orden dórico según el modelo de Vignola, y por encima pilastras y traspilastras de piedra berroqueña de dos piezas de anchura y fustes de once hiladas de pie y medio de altura hasta el collarino. Capiteles, arquitrabes, cornisas, fajas y lunetas eran del mármol citado, así como cuatro arcos dovelados con lecho de pie y medio que se situaban por encima de la cornisa. Éstos, sus cuatro pechinas y un pedestal moldurado superpuesto también de mármol sostenían la media naranja que cubría el espacio, fajeada, con yeserías pintadas al óleo o temple fingiendo mármol serpentino y piedra berroqueña en las partes correspondientes a los pies derechos. Traspasado este ámbito, se abría el presbiterio, cubierto con bóveda de dos tramos, con sus fajas, recuadros y lunetas. El solado de la capilla, el frente del altar, unas gradas que se extendían detrás de él hasta el cabecero de la capilla y el propio suelo que se extendía sobre las gradas y hasta el cabecero -a modo de transparente-, serían de mármol blanco y negro de Portugal ${ }^{7}$. Detrás de la cabecera se dispuso la sacristía, más modesta en sus materiales; subiría lo que permitiera la capilla de don Gabriel de Ugarte $^{8}$, cuya luz no podría obstruir ${ }^{9}$.

Al exterior, la fábrica de la nueva capilla se compondría de dos hiladas de sillares de piedra berroqueña de pie y medio de altura y por encima albañilería de ladrillo colorado hasta topar con la cornisa, de ladrillo o piedra. La cúpula llevaría encima una armadura a cuatro aguas con buhardas, bola, pedestal de plomo o pizarra y veleta. La bóveda del presbiterio se cubriría a tres aguas, al modo de la capilla mayor de la iglesia. Las puertas de ingreso a la capilla, exterior e interior, eran de piedra berroqueña en cuanto a las gradas de ingreso, pilastras y pies derechos, y de mármol serpentino las cornisas, arcos, cartelas, frontispicio, escudos y tarjetas. El 2 de marzo de 1630 firmó Bartolomé Díaz Arias la provisión y precios de piedra berroqueña y mármoles y el 4 de mayo se obligó a hacer la capilla.

Aunque las condiciones estaban suscritas por Pedrosa, Tovar dedujo que Gómez de Mora era el autor de la traza y planta a las que se refiere el maestro cántabro. Destacó su influencia en los proyectos posteriores por su disposición paralela a la nave de la iglesia ${ }^{10}$. Estamos conformes con la atribución al maestro mayor de la Villa del proyecto desarrollado por Pedrosa pero no con la otra apreciación, porque, como hemos dicho ya, Tovar interpretó que el proyecto era el del dibujo de 1639, sin percatarse de que lo descrito en él es una capilla dentro de la iglesia de San Andrés, mientras que las condiciones de Pedrosa describen una capilla añadida al exterior. En

\footnotetext{
7 El maestro de la obra tendría únicamente que asentar las rejas, que se le darían hechas.

8 El documento contiene el apellido Duarte, confundido con Ugarte por similitud.

9 Tendría puertas y ventanas de madera de Cuenca y tableros de nogal con sus fallebas, cerraduras y aldabas, solado de ladrillo de Toledo, cubrición de bovedillas de madera y armadura en forma de colgadizo.

10 TOVAR, Juan Gómez de Mora ..., op. cit., pp. 232-233. Según Tovar, era una idea a la que ya habría acudido Gómez de Mora en 1612 para la capilla de Nuestra Señora de Atocha; esta capilla fue ideada por Francisco de Mora a fines del siglo XVI. Precisaremos que los diseños a que alude Tovar (Archivo Histórico Nacional, Estado, leg. 2620 y Archivo Histórico de Protocolos de Madrid (A.H.P.M.), prot. 2844, fol. 1057) son prácticamente idénticos y están fechados el mismo día, 9 de junio de 1612, por lo que se trata de un original y su copia, y no fueron para la capilla real del Monasterio, sino para la nave de la iglesia del convento dominico, tal como reza el texto de uno de los dos.
} 
cuanto al ornato interior, cuyo moderno estilo barroco también destaca la estudiosa por la abundancia de mármoles, nos parece que es acorde con su época e incluso más contenido que los proyectos para la capilla de la Virgen del Sagrario de Toledo de Nicolás de Vergara y Juan Bautista Monegro (1604-1618) o el Panteón del Escorial de Giovanni Battista Crescenzi (trazado en 1618). Aunque el debate historiográfico en los últimos años se ha dividido a favor del italiano o del conquense, se trata de conceptos distintos de la arquitectura en cuanto a estética y economía. Gómez de Mora no practicaba una austeridad decorativa solo por tradición escurialense, sino que, en general, deseaba acelerar la construcción evitando el uso excesivo de materiales y adornos costosos. En nuestra opinión, es destacable el cromatismo severo elegido, el mármol gris oscuro, abundante en la parte baja alternado con el gris claro de la piedra berroqueña, fingiendo ambos materiales en parte de los abovedamientos, que adquiere mayor contraste -blanco y negro- en los mármoles portugueses del solado y otros adornos, mientras el exterior sigue la clásica combinación de los edificios madrileños, en ladrillo con toques berroqueños. El orden debió ser el dórico de Vignola pese a especificarse únicamente en el basamento, según explicaría trece años después el arquitecto real, por ser el más adecuado a la piedra y mármol, ya que era menos complicado en sus elementos y por tanto más barato ${ }^{11}$.

Nada sabemos de las razones por las que no se llevó adelante un proyecto para el que ya se había elegido maestro ejecutante. Tan sólo podemos apuntar que son los mismos momentos en que se detenía la fábrica escurialense por falta de caudales ${ }^{12}$. Acaso no fueron casuales los nombramientos en 1630 de Crescenzi como superintendente de las obras reales y de Carbonel como aparejador mayor, permitiéndoles acapararar en los cinco años siguientes las empresas de la Corona, siendo apartado Gómez de Mora, inmerso en acusaciones de fraude a la misma. No obstante, como no hay referencia a una intervención real, es más probable que se detuviera por ser el espacio pequeño o por falta de dinero, como sucedió en intervenciones posteriores.

\section{Gómez de Mora y su reforma de la capilla mayor de la iglesia parroquial de San Andrés (hacia 1636)}

Según el importante informe ya citado del regidor don Juan de Cuero y Tapia, emitido bajo el corregimiento de don Francisco Arévalo de Zuazo ${ }^{13}$, sabemos que, después,

11 En general era el sentir de los maestros de obras en aquel momento, como veremos al tratar el proyecto de Pedro de la Torre de 1642.

12 La guerra de la Valtellina hacía prever grandes gastos bélicos, que quizá fueron causa de la detención de las obras arquitectónicas patrocinadas por la Corona, aunque el Concejo madrileño podía no estar tan directamente afectado.

13 Toda esta documentación inédita, fechada desde el 7 de noviembre de 1639 hasta el 18 de marzo de 1642, está contenida en el A.V., A.S.A. 2-283-4. Un pequeño extracto del informe de Tapia fue transcrito por CIRIA, H., "San Isidro Labrador”, La Semana Católica, XVI (1897), pp. 563-564 y 583-584. Solamente fue comentado, sin interpretar correctamente su contenido, por FERNÁNDEZ TALAYA, María Teresa, "La capilla de San Isidro en la iglesia de San Andrés", en VV.AA., San Isidro y Madrid, Madrid, Instituto de Estudios Madrileños, 2011, pp. 141-165, concretamente pp. 143-144. 
se quiso renovar la capilla mayor de San Andrés con nueva bóveda, supresión de los colaterales y la tribuna, y construcción de gradas y retablo con transparente para la urna del Santo y el Santísimo Sacramento en el sagrario.

"Y haviéndose juzgado se podía disponer decorossamente hermoseada la capilla mayor de bóveda moderna, quitando los colaterales y haciendo gradas y retablo de estimación y detrás dél un transparente y capilla reservada en que pudiese estar continuamente descubierto el Santísimo Sacramento del altar mayor como sagrario dél y del santo, resistió este intento la dicha doña Catalina de Luján, haciendo queja de aver entrado a ver el sitio, que es un corralillo que parte dél se avía de ocupar, y un pedaço del edificio de un aposento de su casa, ocupando ansimismo la tribuna que sale dellas muy junto al retablo del altar mayor al lado de la epístola, que ni con la traça podía quedar ni se pudiera permitir para la decencia ni para la estimación y respeto del patronazgo desta Villa, cuyo ayuntamiento en los actos públicos fuera notado asistir con la superioridad de aquel lugar, digno sólo para la casa de su magestad, y aunque esto se a procurado después de la muerte de la dicha doña Catalina, no se a podido conseguir con su hijo, haviéndole embiado las trazas que hiço Juan Gómez de Mora y las razones que le pudieran obligar".

Hemos de relacionar con este intento el dibujo del Museo del Prado que, procedente de la colección real, ha sido adjudicado siempre a Alonso Cano. Lo allí diseñado coincide con toda exactitud con la descripción que hace Tapia del proyecto de Gómez de Mora, una rara combinación de un altar que era a la vez relicario para la urna de San Isidro y mayor de una parroquia dedicada a San Andrés. Responde el dibujo al carácter de rasguño para plasmar de forma rápida la idea del Concejo, por sus reducidas dimensiones y poca definición ${ }^{14}$. El marco del lienzo de San Andrés tiene un adorno simplemente comenzado; el trazo de algunos elementos ornamentales, como festones o cogollos, es poco preciso. Otros aspectos iconográficos apoyan esta identificación: la custodia carece de remate para servir de pedestal a la urna, incluyéndose ambas en un espacio carente de respaldo, visible desde atrás del altar, a modo de transparente. El segundo cuerpo se adorna con imágenes de bulto de San Isidro y Santa María de la Cabeza en las entrecalles, relacionadas con la urna, mientras en el centro, el lienzo del Martirio del santo titular y los Doctores de la Iglesia Latina en el ático aluden a la función parroquial. La terminación en medio punto responde al proyecto de sustituir la bóveda de crucería de la capilla mayor de San Andrés por una bóveda de cañón.

Lo atribuimos a Juan Gómez de Mora no sólo por la alusión al autor del proyecto que hace el regidor Tapia, sino también por razones estilísticas. De forma reciente se ha demostrado documentalmente que eran del maestro mayor varias trazas orna-

14 D 3807 . Hecho a pluma y aguada sepia, mide solamente 286 x $124 \mathrm{~mm}$. Compárese con el tamaño de una vara de la traza atribuida a Cano para el trono de la Virgen del Sagrario en la catedral de Toledo (MARÍAS, Fernando, "Alonso Cano y la columna salomónica" en VV.AA., Figuras e imágenes del Barroco. Estudios sobre el barroco español y sobre la obra de Alonso Cano, Madrid, Fundación Argentaria, 1999, pp. 291-321, concretamente p. 301) o la limpieza y detalle del dibujo de su seguidor Herrera Barnuevo para el tabernáculo de San Isidro (Biblioteca Nacional de España). 
mentales con figuración atribuidas antes al granadino, como las de la fuente de la plaza de la Cebada de 1617 (Museo de Historia de Madrid), o del retablo del hospital madrileño de Antón Martín de 1633 (Museo del Prado) ${ }^{15}$, respectivamente anteriores en veinte y en cinco años a la llegada de Cano a la Corte ${ }^{16}$. Tampoco la del retablo de San Diego de Alcalá es suya, sino de Sebastián de Benavente (1653, Pierpont Morgan Library de Nueva York) ${ }^{17}$.

La estructura y los elementos arquitectónicos son muy similares en las trazas para Antón Martín y San Andrés: tres cuerpos proporcionados, custodia inscrita en arco con jambas en el primer cuerpo, entablamentos completos en este cuerpo y en el segundo y casi inexistentes en el tercero, cuatro columnas en el central, transparente para la Virgen del Amor de Dios en uno y para la urna de San Isidro en el otro, remate con estribos o aletones, cerchones moldurados y frontispicios curvos.

Por lo que respecta al ornamento, hay también muchas coincidencias, como los festones colgantes dobles en el friso del primer cuerpo de Antón Martín y en el remate en San Andrés, o las mal llamadas tarjetas canescas, caracterizadas por su carácter vegetal barroco frente al de placa manierista ${ }^{18}$. El marco del remate conventual y el del lienzo de San Andrés tienen únicamente empezada la decoración de cuentas. Finalmente, hay paralelos en la figuración, en las imágenes de San Juan de Dios y San Isidro, de San Rafael y Santa María de la Cabeza, y de la Virgen y San Juan con los Doctores que están de pie en contrapposto; las composiciones presentan divergencias inevitables en episodios distintos, pero hay posturas paralelas como el enfermo socorrido por san Juan de Dios, recostado como el testigo del martirio de san Andrés, además de plegados, cabezas y otros detalles.

Parecen argumentos estilísticos más que suficientes para atribuir a Gómez de Mora el dibujo de San Andrés, pese a no haber más retablos suyos de este momento con qué comparar. Rodríguez G. de Ceballos señaló el clasicismo de ambas trazas pero mantuvo la atribución a Cano ${ }^{19}$. Hemos aclarado que éste practicó un estilo persona-

15 Atribuída con reservas por MARÍAS, op. cit., p. 291, y sin ninguna en CRUZ YÁBAR, Juan María, "El retablo mayor del monasterio jerónimo de Santa María de Espeja. Una vieja y una nueva visión", Archivo Español de Arte, 334 (2011), pp. 125-138, espec. pp. 133-134.

16 Poco o nada tiene que ver con el estilo dibujístico de los más acreditados tracistas de retablos que, como veremos, se presentaron a los concursos para capilla de San Isidro: Alonso Carbonel, Pedro de la Torre, Francisco Bautista y fray Lorenzo de San Nicolás, ni el propio Alonso Cano, del que se conserva el del Cristo camino del Calvario o la Concepción del convento de San Alberto de Sevilla y el del pilar de Santa Catalina en la parroquial madrileña de San Miguel.

17 CRUZ YÁBAR, Juan María, "Sebastián de Benavente y la capilla de San Diego de Alcalá", Archivo Español de Arte, 324 (2008), pp. 379-394. IBIDEM, Sebastián de Benavente (1619-1689) y el retablo cortesano de su época, Madrid, Universidad Complutense, 2013, t. I, pp. 207-212 y t. II, 289-307. IDEM, "El retablo de San Diego de Alcalá y los arquitectos Francisco Belvilar, Sebastián de Benavente y Pedro de la Torre", Anales del Instituto de Estudios Madrileños, LIV (2014).

18 Al menos presentes en Madrid desde 1633 en este retablo de Gómez de Mora, cinco años antes de la llegada de Cano.

19 RODRÍGUEZ G. DE CEBALLOS, Alfonso, “Alonso Cano y el retablo”, en VV.AA., Figuras e imágenes del Barroco: estudios sobre el Barroco español y sobre la obra de Alonso Cano, Madrid, Fundación Argentaria, 1999, pp. 251-270. 
lísimo, al prescindir de los órdenes clásicos y crear nuevos ornamentos, algo que no reflejan los retablos de que hemos tratado ${ }^{20}$.

El dibujo ha sido fechado en general entre 1640 y 1645. Solamente García Hidalgo lo ha datado en $1657^{21}$, porque unas fuertes lluvias que causaron el desplome de la cubierta parroquial el año anterior dieron pie a la reforma de la cabecera poligonal antigua por una recta más amplia ${ }^{22}$, pero lo que se trazó a raíz de ese suceso fue la capilla definitiva para el Santo. El informe de Tapia obliga a datar este proyecto de retablo de San Andrés y San Isidro de Gómez de Mora, el único documentado en la obra de la capilla del Santo, hacia 1636 por los acontecimientos que expondremos a continuación.

\section{El primer concurso para capilla ganado por Alonso Carbonel (1638)}

Retomamos el informe de Tapia, tras el fracaso de la reforma de la capilla mayor de Gómez de Mora por negarse la propietaria del espacio colindante a ceder nada a la iglesia.

"Con estas resistencias e impusivilidades se delinió el edificio de esta capilla en la de don Graviel de Ugarte, que está su reja dentro de la mayor al lado de la epístola, y por estar en la Nueva Spaña, se procuró barias bezes con diferentes personass, sus deudos y correspondientes, la dación desta capilla, y no se pudo empezar a poner en execución hasta que haviendo venido a esta Corte con su poder don Graviel de Ugarte y Ayala, su hijo, la ofreció a Madrid, solicitando con su magestad hiciese merced a su padre del correjimiento de Tascala y de un hávito para su hijo, y haviéndose conseguido, no se pudo conseguir perpetuidad del contrato porque no se trujo los papeles, recados y títulos de la tal capilla ni constó ser de patronazgo perpetuo ni temporal ni de bienes libres, con que por estar próxima la yda de la flota se advirtió se le diese el título del corregimiento y decreto del ávito, obligándose a embiar en la siguiente flota que biniese destos reinos después de llegar a los de la Nueva Spaña la que estava de partida, todos los recaudos necesarios y ratificación de la scritura y fianças, que se otorgó en 26 de los meses de febrero y de março del año de 1640 ante Francisco Suárez de Ribera, scrivano del número, con que para tener ligítimo título es menester consumar este acto con la ratificación y papeles que se esperan, si bien se a tenido carta del dicho don Graviel, su fecha de México y 25 del mes de noviembre del mismo año, en que avissa que los embiará..."

20 CRUZ YÁBAR, Sebastián de Benavente..., op. cit., pp. 386-390.

21 GARCÍA-HIDALGO, Cipriano, "Sebastián de Herrera Barnuevo y su intervención en la capilla de San Isidro de Madrid", Cuadernos de Arte e Iconografia, 32 (2007), pp. 357-384. Es de la misma opinión RODRÍGUEZ REBOLLO, Ángel, "A propósito de Alonso Cano: el dibujo para el retablo de San Diego de Alcalá y su homónimo para San Andrés”, en VV. AA., In sapientia libertas. Escritos en homenaje al profesor Alfonso E. Pérez Sánchez, Madrid, Museo del Prado, 2007, pp. 452-458.

22 El dibujo, aunque no tiene planta, corresponde a un testero recto, como se deduce por medio de la posición de soportes, entablamentos y enjutas del retablo, que tiene los extremos adelantados respecto a la parte central para rellenar el espacio. La custodia está ante un nicho que hace de transparente. 


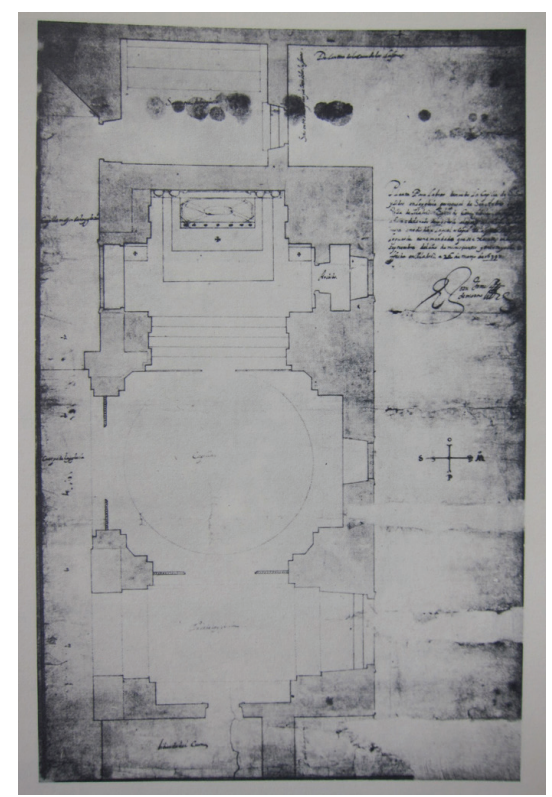

Fig. 1. Alonso Carbonel (copia de Juan Gómez de Mora). Traza para la capilla de San Isidro de Madrid. 1638. Archivo de Villa.

La salida contemplada por el concejo madrileño tras abandonar la idea de un retablo relicario para San Isidro fue la de emplazar la capilla dentro de la iglesia, en el lado de la epístola. Para ello se necesitaba ocupar el espacio de la capilla de don Gabriel de Ugarte. Los tratos con este caballero habían comenzado en la década de los veintes, según comentamos más atrás, y debieron reanudarse al menos en la primavera de 1637. Otro informe inédito de Tapia, éste de $1640^{23}$, da noticia de que don Gabriel dio poder en la ciudad de México a su hijo homónimo el 17 de julio de 1637 para poder vender, donar o trocar la capilla, a cambio de que la Villa obtuviera del Rey el corregimiento, un altar y sepultura en otra parte de la iglesia para él y sus descendientes, y un hábito de Santiago para su vástago. En sesión del Ayuntamiento del 28 de julio de 1638 se agradeció a Ugarte la cesión de su capilla para que se pudiera hacer la de San Isidro, y se encomendó a don Juan de Tapia y don Diego de Urbina hacer ante el Rey, el valido y demás ministros las diligencias necesarias para compensarle ${ }^{24}$.

Acto seguido se convocó un primer concurso para capilla, desvelado hace años por Cruz Valdovinos $^{25}$. El 20 de agosto de 1638 dio cuenta el regidor Urbina a la junta del Ayuntamiento de su entrevista junto a otro regidor -sería Tapia-con el Rey y el

238 de marzo (A.V., A.S.A., 2-283-4).

24 A.V., Libro de Acuerdos nº 55 (1637-1638), fol. 139.

25 CRUZ VALDOVINOS, José Manuel, "Las etapas cortesanas de Alonso Cano", en Alonso Cano. Espiritualidad y modernidad artística, Granada, Junta de Andalucía, 2001, pp. 177-213, concretamente pp. 201202. 
Conde-duque, quien mandó, en vista del interés de la Villa por hacer la capilla, que se hiciese traza y se le enviase. El pleno acordó que los mejores maestros hicieran dibujos, y se nombró a Cristóbal de Medina comisario de la obra ${ }^{26}$. Ordenó Felipe IV el 12 de septiembre que se hiciera la traza elegida, según conocemos por la inscripción de la traza erróneamente atribuída a Gómez de $\mathrm{Mora}^{27}$; por tanto la convocatoria y elección de la traza tardó tres semanas en resolverse.

El 17 de noviembre se leyó en la Junta un papel del 14 del presidente de Castilla, a la sazón el arzobispo de Granada don Fernando de Llano y Valdés, por el que remitía la planta firmada por Carbonel para la capilla, que el Rey mandaba ejecutar, reuniendo fondos para ello ${ }^{28}$. Aunque se ha dado siempre por perdida, esta planta de Carbonel de 1638 fue copiada por alguno de sus colaboradores y enviada por la administración real a la Villa, con texto explicativo fechado el 26 de marzo de 1639 firmado por Gómez de Mora en su función de maestro mayor de Madrid.

Gómez de Mora advirtió en el dibujo que la fábrica de la capilla saldría once pies fuera de la nave del mediodía de la iglesia, tirando los entrepaños de la pared exterior y revistiendo las pilastras para el nuevo recinto, aprovechando los pilares del cuerpo principal. El informe de Tapia alude a esta ampliación del recinto destinado a la capilla y a los inconvenientes que se plantearían:

"Y dado casso que en la parte antecedente se ayan vencido las dificultades que an resultado y resultan para el yntento, las de ser pequeño el sitio y ser forzoso ocupar parte del cimenterio a la larga dél, estrechándose la entrada principal que para los concursos se necesitava más anchurossa, quitando el edificio la vista, ayre y sol a algunas ventanas de la delantera en que está la puerta de la cassa del dicho don Fadrique..."

Tras la ocupación de la capilla de los Ugartes y la ampliación a expensas del espacio exterior de la iglesia donde se hallaba el cementerio, las medidas se aproximaban a los 80 × 35,5 pies, equivalentes a 22,40 x 10 metros. El dibujo de Carbonel muestra

26 Archivo de Villa, Libro de Acuerdos no 55 (1637-1638), fol. 132v: "En este Ayuntamiento, abiéndose dado quenta por los señores don Diego de Urbina y don Diego de Urbina (sic) como para la fábrica de la capilla de San Ysidro an ablado a su Magestad y señor Conde duque, y que su excelencia el señor Conde duque les abía echo mucha merced y estimado el cuidado desta Villa, y mandado se hiciese traça para esta obra de fábrica muy suntuosa y se le llebase para berla, y abiéndolo oydo, se acordó que se hagan las trazas por los mejores maestros que se allare y se lleben al señor Conde duque, y para ello se nombra al señor Cristóbal de Medina por comisario para esto y para la fábrica della".

27 "Planta para labrar de nuebo la capilla de señor San Ysidro en la yglesia parroquial de San Andrés en esta villa de Madrid, saliendo con su fábrica once pies más afuera de la nabe de la yglesia a la parte que mira a mediodía, la qual es copia de la que su Magestad, Dios le guarde, tiene mandado que se execute en doce de septiembre del año de mil seiscientos y treinta y ocho, fecha en Madrid a 26 de março de 1639. Joan Gómez de Mora".

28 IBIDEM, fol. 204v: "Remito a vuesa merced esa planta firmada de Alonso Carbonel de la capilla que se a de hacer en la yglesia parroquial de San Andrés donde se a de poner el cuerpo del glorioso San Ysidro, la qual me a enviado su Magestad, y mande se execute en la forma que ba dispuesta. Así lo dirá vuesa merced a la Villa y cuidará de la execución. Presidente de Castilla a vuesa merced. Madrid, catorce de noviembre de 1638. Está rrubricado de su señoría ilustrísima. Al corregidor de Madrid y abiéndose visto dicho papel y traza se acordó se haga y execute lo que su Magestad, Dios le guarde, manda, y para que tenga efeto los señores comisarios se junten y vean los efetos de dineros que sean nezesarios para la dicha fábrica y de dónde se podrán hacer" (CRUZ VALDOVINOS, “Las etapas...", op. cit., p. 202). 


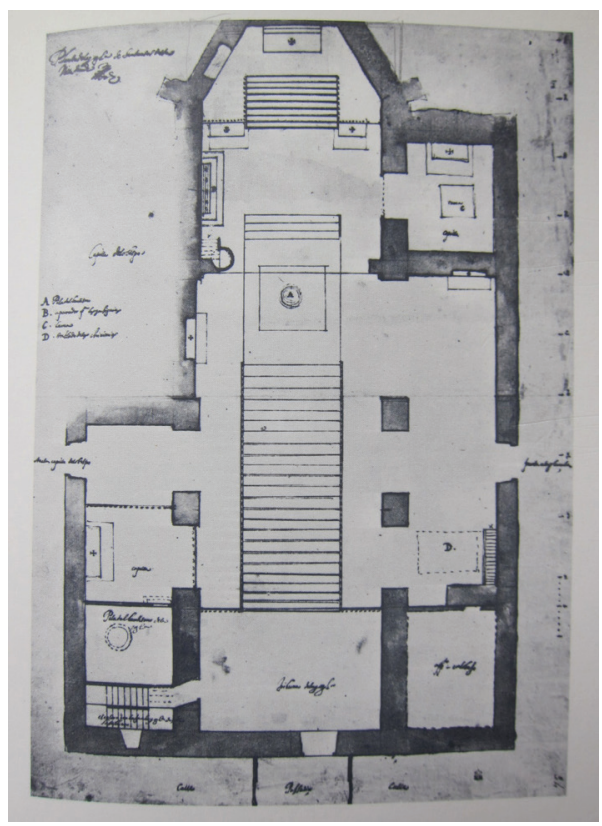

Fig. 2. Juan Gómez de Mora. Planta de la iglesia parroquial de San Andrés de Madrid. 1626. Palacio Real de Madrid.

un presbiterio con altar principal, custodia con la urna y retablo de columnas pareadas a cada lado $^{29}$, dos estrechos altares colaterales, cinco gradas, estancia para archivo, cuerpo principal cupulado y otro pequeño espacio inmediato a la entrada desde la calle. La capilla comunicaba con la iglesia mediante dos arcos entre los pilares, separados seguramente por rejas, y tenía su entrada principal por los pies, inmediatos a la puerta de la plazuela.

No se puede deducir el alzado interior ideado por Carbonel mas allá de los soportes, pero podemos guiarnos por una obra que trazó justo después, el relicario de la capilla real del Alcázar, realizado entre 1640 y $1643^{30}$, donde siguió a su mentor Crescenzi en el orden corintio y en los materiales (bronces, mármoles y jaspes rojizos), aunque la presencia de los relicarios exigió en ellos columnas, jaspe verde y maderas ricas.

Tampoco llegó a buen fin este proyecto. Los desvelos de la Villa para adquirir la capilla de los Ugartes dieron fruto, y Felipe IV le concedió el corregimiento de Tlaxcala por orden del 16 de noviembre de $1638^{31}$, según carta del secretario del Consejo de

29 Rematarían dos columnas un probable segundo cuerpo con frontispicio.

30 Sobre esta obra de Carbonel es de obligada consulta el novedoso y completo trabajo de BLANCO MOZO, Juan Luis, Alonso Carbonel (1583-1660), arquitecto del rey y del conde-duque de Olivares, Madrid, Fundación Universitaria Española, 2007, pp. 208-212.

31 Macho Ortega proporcionó la fecha errónea de 1628 (MACHO ORTEGA, Francisco, "La capilla de San Isidro en la parroquia de San Andrés de Madrid", Boletín de la Sociedad Española de Excursiones, XXVI (1918), pp. 216-222). Además sabemos por el informe de Tapia de 1640 que mandó se despachara cédula para el habíto de Santiago requerido. 
Indias don Gabriel de Ocaña y Alarcón del 7 de noviembre de 1639 32 . Para la cesión y traspaso de propiedad de la capilla de Ugarte se otorgó escritura pública el 26 de febrero de $1640^{33}$, dándole en permuta una sepultura y altar ${ }^{34}$. Aún así seguía siendo pequeño el sitio y su ampliación se preveía litigiosa, por la presencia del cementerio y el perjuicio de las vistas y luces de la casa de don Fadrique Enríquez, además de la necesidad de trasladar un altar de doña Gimena de Vargas y sepulturas parroquiales y de particulares. Pero debieron ser los problemas económicos derivados de las revoluciones de Portugal y Cataluña los que dieron al traste con el proyecto de Carbonel, y buena prueba supone la lentitud de los trámites; la copia de la traza está firmada por Gómez de Mora más de medio año más tarde de su elección por el Rey. Es posible que el Ayuntamiento madrileño no encontrara demasiado estímulo en llevar a término un proyecto nacido de un concurso en el que no había intervenido apenas y en que el ganador había sido el arquitecto del Conde-duque y no el maestro mayor de la Villa.

32 Pedía el secretario real al de la Villa que notificara la merced a Madrid y tuviera seguridad de la oferta de la cesión, para que constara en la secretaría de Indias y así pudiera sacar despacho (ASA, 2-283-4).

33 A.H.P.M., prot. 6202, fol. 878-883v. Escritura de venta de la capilla con presencia del capitán don Juan de Cuero y Tapia, como comisario de las cosas tocantes a San Isidro, entre el cura don Alberto Dávila y el mayordomo licenciado Cristóbal Hurtado, de una parte, y de la otra don Gabriel de Ugarte con el poder de su padre. La capilla fue fundada y dotada por Fernán Láinez de Covarrubias, maestre sala de los Reyes Católicos, y su mujer doña Marquesa de Ugarte, tatarabuelos de don Gabriel padre.Tenía por advocación la Santa Cruz, medía seis varas y dos tercias de largo y cinco varas de ancho. Estaba muy maltratada con peligro de hundirse desde hacía mucho tiempo y por ese temor no se celebraban en ella los oficios, ni se reparó por no estar su patrón en la Corte. A cambio del traspaso a la Villa cedieron el cura y mayordomo a Ugarte una sepultura en la capilla mayor, la segunda del lado del evangelio, inmediata al altar que estaba a los pies de la iglesia, bajo el coro y tribuna, frente a la capilla del Santo Cristo, lugar venerado por ser donde se enterró a San Isidro, cuyo altar podían utilizar los Ugartes para celebrar misas y otros menesteres espirituales. Se especificaron las penas y obligaciones citadas en el escrito de Tapia y se advirtió que precisaba la operación aprobación del gobernador del Arzobispado. Al final figura el traslado el 5 de febrero de 1640 desde el oficio de Juan Manrique del poder otorgado en 1637 por el padre al hijo, que iba a partir entonces a España, dado asimismo a su cuñado el santiaguista don Alonso Verdugo de la Cueva y Sotomayor, y su hermano, don Bernardino de Ugarte y Ayala, caballero de San Juan, que fue uno de los testigos en América. La fianza y su abono en A.H.P.M., prot. 6202, fol. 960-963v, en la que don Gabriel obligó a su hermano don Antonio como poseedor del mayorazgo. El altar cedido a la familia se llamaba de la Traslación de San Isidro; contenía un retablo hecho por Antonio de Herrera (vid. DÍAZ MORENO, Félix, "El antiguo retablo de San Isidro en San Andrés de Madrid, traza del escultor real Antonio de Herrera", Anales del Instituto de Estudios Madrileños, XLVI (2006), pp. 1015-1022).

34 El Consejo de la cámara debía aprobar el contrato en lo tocante al vínculo, mayorazgo y patronazgo de don Gabriel, pero eran necesarios los escritos y títulos, que tenía don Gabriel en Nueva España, quien necesitaba que en la flota que iba para allá fuera el título de la merced. Consultado uno de los abogados de la Villa se decidió que, para que el contrato quedara a resguardo y pudiera despacharse el título, debía obligarse don Gabriel hijo a que su padre enviaría en la siguiente flota los títulos y recaudos más la escritura de cesión ratificada por él, su hijo mayor don Antonio de Ugarte y Ayala y su hijo don Gabriel, que entregarían a la Villa a través de don Juan de Tapia. Si incumplieran y pasara el plazo, pagarían lo que se labrase y adornase en la capilla de San Isidro y 6.000 ducados u otra pena a elección de la Villa por el corregimiento y el hábito. La fianza la hicieron ante el Consejo el santiaguista don José de Sarabia y don Gabriel de Ugarte hijo, y la abonó el regidor don Miguel de Haro. El pleno acordó que el secretario del Ayuntamiento avisara a los oficios de Indias y de Órdenes de que la Villa estaba satisfecha y se podía librar el título y cédula a favor del padre y el hijo, y se les recomendara por escrito al electo virrey de Nueva España, marqués de Villena (Informe de 1640). 


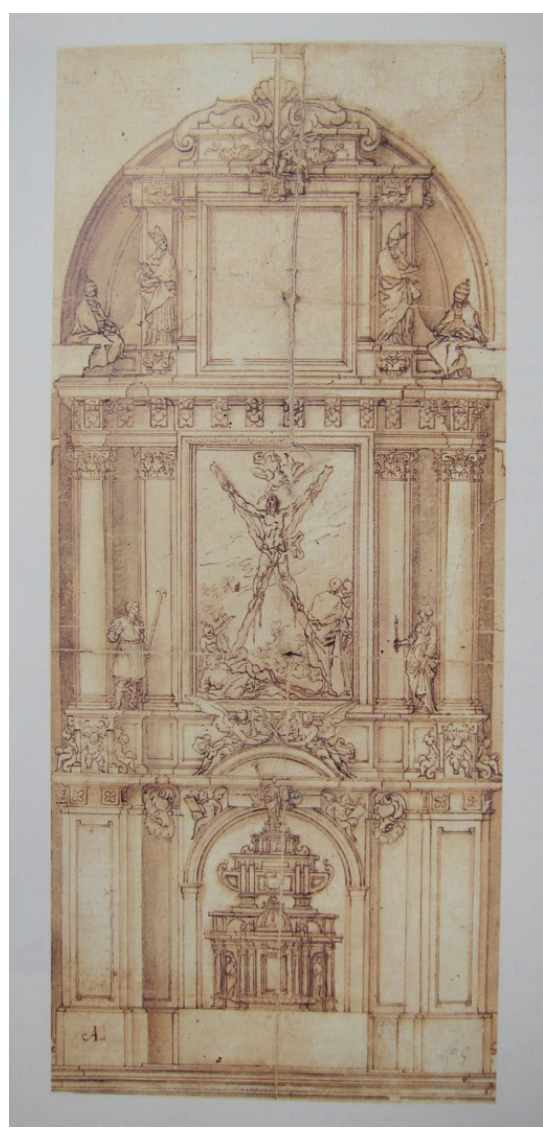

Fig. 3. Juan Gómez de Mora. Traza para el retablo mayor de la parroquial de San Andrés de Madrid. H. 1636. Museo Nacional del Prado.

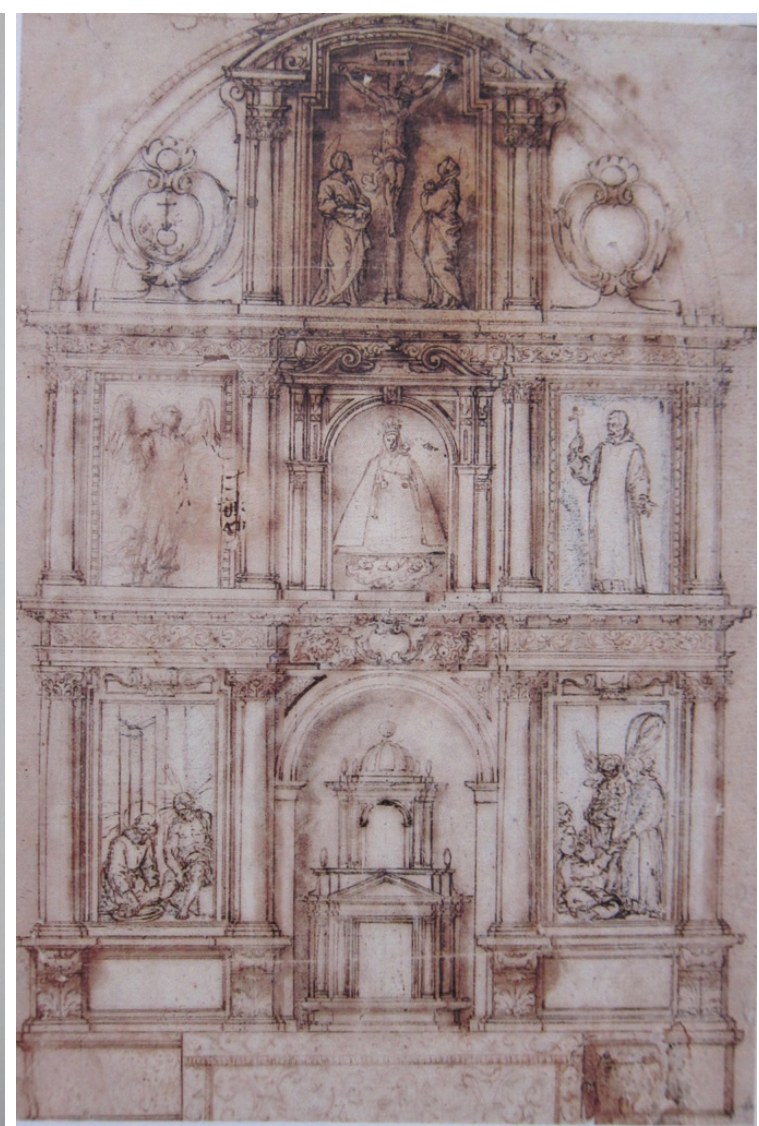

Fig. 4. Juan Gómez de Mora. Traza para el retablo mayor del convento de Antón Martín de Madrid. 1633. Museo Nacional del Prado.

\section{Pedro de la Torre vencedor del segundo concurso, de iglesia de San Andrés y capilla del Santo (1642)}

El 18 de junio de 1641 deliberó el Ayuntamiento acerca de qué debía hacerse tras las dos últimas experiencias, lo que provocó que se encargara el informe comentado a don Juan de Tapia, cuyos resultados expuso el 2 de julio siguiente. El regidor reconocía que la mejor solución era la de colocar al Santo en el retablo mayor, por ser el presbiterio la parte principal de un templo y el lugar donde estaban colocadas las imágenes de Vírgenes de gran devoción, como la de Montserrat. No obstante, ante la oposición de don Fadrique Enríquez a que se tomara parte de sus casas, lo que constituía un obstáculo para ensanchar el presbiterio, apuntaba la posibilidad de buscar 
otro lugar en la iglesia o incluso llevar el cuerpo del Santo al nuevo ayuntamiento que se estaba labrando ${ }^{35}$.

Pero el concejo madrileño seguía en su propósito de reformar la iglesia de San Andrés o de hacer una capilla particular para San Isidro. El mismo día en que don Juan de Tapia exponía su informe, se ordenó que Gómez de Mora y el jesuita Francisco Bautista fueran con los comisarios y determinaran el mejor emplazamiento para la capilla. El 23 de julio de 1641 encomendó la Junta a Tapia que pidiera a la condesa de Paredes la venta del corral de sus casas para alargar la capilla mayor de la iglesia de San Andrés y hacer capilla propia a San Isidro, lo que explica la demanda a varios arquitectos de un doble proyecto como diremos a continuación. La condesa de Paredes, doña María Inés Manrique de Lara, era hija de una hermana de don Fadrique Enríquez, y pudo haber heredado parte de las casas que habían sido de su abuela doña Catalina de Luján. En todo caso, heredó los mayorazgos de su tío don Fadrique Enríquez, que no tenía sucesión directa y que moriría en $1660^{36}$. No cabe duda de que la situación había cambiado, pues el Concejo logró ahora lo que antes no habían conseguido. Con ello se abrían las posibilidades de reformar y extender la cabecera del templo, o bien de hacer una nueva capilla para el Santo.

En este contexto encaja el siguiente proyecto fallido, el de Pedro de la Torre de 1642, conocido, aunque mal interpretado. Desde Wethey se piensa que este proyecto había sido elegido en torno al 10 de mayo de 1642 en un concurso al que comparecieron este maestro, Gómez de Mora, Bautista, el agustino recoleto fray Lorenzo de San Nicolás y los maestros de obras Miguel del Valle y Cristóbal Colomo, y que hacia 1645 se detuvo la fábrica ${ }^{37}$. Las noticias que damos a conocer llevan a conclusiones distintas. El 28 de enero de 1642 se vieron por la Junta todas las trazas que trajeron solo cuatro maestros, Gómez de Mora, el hermano Bautista, fray Lorenzo y Pedro de la Torre, y se acordó que el 15 de febrero viniera cada uno de ellos sólo con dos diseños, uno de iglesia para el Santísimo Sacramento y San Isidro ${ }^{38}$, y otro de capilla, que eran las dos opciones contempladas hasta el momento. El 5 de marzo eligió la Junta un dibujo de cada maestro y mandó que se enviaran con el parecer de sus miembros al presidente de Castilla, don Diego de Castejón y Fonseca, para que las consultara con el Rey, quien debía elegir una de ellas ${ }^{39}$. El 18 de ese mes se aprobó la remisión

35 La salida del cuerpo de la parroquia de San Andrés causaría perjuicio a ésta, pero no había demostrado interés en tenerlo, y se tendría que conformar con que la nueva capilla del Ayuntamiento fuera filial de la parroquia, recibiendo una limosna anual para su fábrica y sus curas una capellanía de misas y vivienda, más sacristán para cuidado de la capilla. Otro inconveniente, que la fábrica nueva del Ayuntamiento se alargara, no le preocupaba, pues los caudales llegarían.

36 ÁLVAREZ Y BAENA, José Antonio, Hijos de Madrid ilustres en santidad, dignidades, armas, ciencias y artes, Madrid, Benito Cano, 1790, t. II, p. 3. La condesa de Paredes había sido aya de la infanta María Teresa, por lo que era una persona de gran influencia en la Corte.

37 WETHEY, Harold E., "Sebastián de Herrera Barnuevo", Anales del Instituto de Arte Americano e Investigaciones Estéticas, 11 (1958), pp. 11-65, espec. p. 15.

38 No parece que pueda situarse aquí el dibujo de retablo del Prado. Resulta difícil imaginar que Gómez de Mora u otro concursante se entretuvieran en diseñar un retablo para iglesia de San Andrés y San Isidro cuando ni siquiera se había elegido su plan para la misma.

39 A.V., A.S.A., 2-283-4. "En Madrid, miércoles cinco de março de mill y seiscientos y quarenta y dos años, se juntaron en una de las salas del ayuntamiento de la dicha Villa los señores don Francisco Arévalo de 
de las trazas, aunque sin unir la opinión de la Junta ${ }^{40}$. Entre ese día y el 10 de mayo se produjo la elección real. En el citado 10 de mayo los regidores, con el acuerdo de Gómez de Mora, Francisco Bautista, fray Lorenzo, además de Miguel del Valle y Cristóbal Colomo, decidieron que Pedro de la Torre elaborara las condiciones para la nueva capilla, ya que su diseño había sido elegido por el $\mathrm{Rey}^{41}$. Al día siguiente recibió Torre de la Junta la traza original con sus alzados en cinco papeles para que redactara las condiciones.

Interpretamos que la Villa prefería a Gómez de Mora frente a los otros candidatos para trazar y dirigir la obra. Su nombre aparece siempre en primer lugar de los arquitectos frente a Pedro de la Torre, relegado al último puesto. La Junta había elaborado unos pareceres en relación con las diversas trazas exponiendo sus preferencias, pero consideraron poco pertinente enviarlas con las trazas a Felipe IV. Debió ser don Diego de Castejón, presidente del Consejo real, quien influyó para que fuera vencedor Pedro de la Torre. Fue protector suyo ${ }^{42}$ y seguramente quien le consolidó en las obras reales ${ }^{43}$.

Çuaço, corregidor della y su tierra, don Pedro de Álava, don Diego de Urbina, don Bernardo de Salas, don Francisco de Luçón y Guzmán y conde de Puñonrrostro, regidores de la dicha Villa, comissarios de la obra para el gloriosso San Ysidro, abiéndose visto las traças que para la dicha obra an hecho Juan Gómez de Mora, maestro mayor de las obras de esta Billa, el hermano Francisco Bauptista, de la compañía de Jesús, fray Lorenzo de San Nicolás, del orden de rrecoletos agustinos, y Pedro de la Torre, escultor, de todas las que an hecho y traído a elegido y elixe esta junta una de cada uno de los susodichos, y la an aprovado y se a acordado que todas las quatro elegidas, que ban firmadas de los dichos señores, se lleven y remitan a su yllustrísima, el señor obispo presidente, a quien se suplique se sirva de consultarlas con su magestad para que de las quatro elija y aprueve la que fuere servido, y con ellas se rremita parezer desta junta de qual de las dichas quatro traças le pareze la más a propósito, y elejida y aprovada por su magestad la que lo fuere, se guarde, cumpla y execute y se llame esta junta para tratar de su execución. Don Francisco de Arévalo y Çuaço. Don Pedro de Álava y Arigón. Don Diego de Urbina. Don Bernardo de Salas. Don Francisco Melchor de Luçón y Guzmán. El conde de Puñonrrostro".

40 IBIDEM. "En Madrid a diez y ocho días del mes de março de mill y seiscientos y quarenta y dos años se juntaron los señores don Francisco Arévalo de Çuaço, corregidor de la dicha Villa y su tierra, don Bernardo de Salas, don Francisco de Luçón y Guzmán, regidores de la dicha Villa, comisarios de la obra para el glorioso San Ysidro. Acordóse que se cumpla el acuerdo desta otra parte y se remitan a su yllustrísima las quatro traças elegidas por esta junta sin el parezer que en el dicho acuerdo se contiene, sino que su magestad y su yllustrísima elixan y aprueven la que fueren servidos".

41 A.V., A.S.A., 2-283-5. Aquí la convocatoria y su resolución tardaron algo más de tres meses, señal de las vacilaciones en cuanto al carácter e idoneidad del plan.

42 Castejón propició la entrada de Torre y Bautista en la obra del Ochavo de la catedral de Toledo hacia 1639 (PÉREZ SEDANO, Francisco, Datos documentales inéditos para la historia del arte español, Madrid, Imprenta de Fortanet y Clásica Española, 1914, p. 90), y pudo ser quien enviara una estampa del trono trazado por estos artífices para la Virgen del Sagrario de esta misma catedral a la de Lugo, donde había sido obispo entre 1634 y 1636, para que sirviera a la de los Ojos Grandes (CRUZ YÁBAR, Juan María, "Pedro de la Torre y Francisco Bautista. Presencia del retablo madrileño en el norte de España", Anales del Instituto de Estudios Madrileños, LI (2011), pp. 101-116, espec. p. 106). Dimos entonces como probable esta hipótesis de MARÍAS, "Alonso Cano...", op. cit., p. 316, señalando la dificultad de que hubiera mandado la estampa a comienzos de 1655, justo antes de fallecer, contratándose a fines de ese año el trono en Lugo, pues la estampa está fechada en 1649, pero este papel protector de Castejón hacia Torre y Bautista refuerza la teoría.

43 El 9 de agosto de 1642 contrató Torre el retablo mayor de la parroquia real de Santiago, según declaró en 1656, hizo el primer cuerpo y custodia por orden de Castejón, superintendente de la obra nombrado por el Rey (CRUZ YÁBAR, Juan María, "Los retablos de la parroquia de Santiago de Madrid. Pedro de la Torre, Sebastián de Benavente y Alonso Cano", Anales del Instituto de Estudios Madrileños, XLV (2005), pp. 155177, espec. p. 166). 
Conviene detenernos en el plan de Pedro de la Torre ${ }^{44}$. Dedicó siete condiciones a cuestiones preliminares de índole práctica ${ }^{45}$. Seguían diecinueve condiciones tocantes a la edificación. El plan de la obra incluía la capilla de San Isidro, reforma del cuerpo de la iglesia, un nuevo atrio y una torre.

Hechos los cimientos de la nueva capilla y su basamento de mármol de San Pablo, el paramento se compondría de pilastras y demás elementos principales del mismo mármol, subiendo hasta la cornisa, con los intervalos de piedra de Torrubia, que el arquitecto pondera: "que por ser blanca y el mármol negro, será agradable, de más de ser muy fuerte". Arquitrabe y cornisa eran de mármol de San Pablo y el friso de piedra blanca. Las bóvedas de la capilla se harían en la misma piedra de Torrubia y de mármol negro los arcos, formas y guarniciones de ventanas. Las gradas del presbiterio, su solado en forma de ajedrez y el adorno del arca de San Isidro se harían en jaspes y mármoles finos, cuya procedencia señalaría en su momento en una memoria. Para la fábrica del cimborrio y bóvedas se remitía a la hechura de un modelo para su mejor comprensión y excusar prolijidad. El tejado se haría en pizarra asentada sobre bovedillas. La capilla disponía de una sacristía y sobresacristía con bóveda y paredes de piedra blanca con un aguamanil de mármol. Para las estatuas, escudos reales y de la villa, basas y capiteles de bronce, rejas y demás talla de la capilla daría posteriormente condiciones cuando conviniera.

Las modificaciones de la iglesia de San Andrés se concentraron en las paredes laterales, la tocante a la nueva capilla y la que quedaba enfrente de ella, por el lado de la capilla del Obispo, que se reedificaban sacándolas de los cimientos y levantando pilastras de piedra berroqueña hasta el entablamento, por encima del cual se fabricarían de albañilería las bóvedas y media naranja con linterna debajo de la armadura del tejado, para lo que se proponía entregar un corte o perfil para mejor comprensión.

Todas las paredes y bóvedas vaídas o de arista del atrio que se había de hacer ante la entrada principal de la iglesia y capilla, por el lado de la plazuela, serían de piedra berroqueña, como su solado de losas, sin hacerlo de más valor por ser lugar muy transitado. La restante cantería de piedra berroqueña en la torre no se explicaba más por mostrarla claramente los papeles.

El proyecto de Torre coincidía con el primero de Gómez de Mora en cuanto al lugar donde se dispondría la capilla, el lado sur, aunque utilizando un espacio mucho más amplio al poder extenderse ya hacia la cabecera de la iglesia y el antiguo recinto

44 Transcribió las condiciones de Pedro de la Torre TOVAR, Arquitectura madrileña ..., op. cit.. En EADEM, Arquitectos madrileños...., op. cit, pp. 132 y 188, se refirió a él someramente, calificándolo de moderno y barroco por formar la capilla un cuerpo independiente, próximo a la solución de 1657 y por eso triunfador sobre el de Gómez de Mora y otros arquitectos. Sin embargo, como demostramos en este trabajo, el terreno del que dispuso fue muy similar al del maestro mayor de 1629 y el aparejador real en 1638.

45 Fueron las únicas transcritas por CIRIA, op. cit., pp. 586-587. Debía haber agua al pie de obra, se harían talleres cercados con tapias y cubiertos para comodidad en el trabajo de los oficiales, con las paredes jaharradas de yeso negro de cedazo para que en ellas se hicieran las muestras necesarias. Convenía también que hubiera dos o tres aposentos para guardar bajo llave trazas y moldes, herramientas y otros pertrechos. Había que hacer una fragua en el taller o cerca del mismo, y arrasar y desescombrar el sitio señalado por la planta para que se tirasen los cordeles sin impedimentos. Las zanjas, sin huecos, se abrirían con media vara más de grosor que el ancho de las paredes para que quedaran zapatas por dentro. El encargado de traer mármoles y jaspes sería un perito para evitar dispendios. 
de la capilla de los Ugartes, del que no podemos saber si quedaba hacia la parte de la iglesia o hacia la nueva capilla del Santo, aunque nos inclinamos hacia la primera posibilidad ${ }^{46}$. La bicromía de 1642 era diferente de la de 1629, pues, además del mármol gris oscuro de San Pablo en basamento, arquitrabe y cornisa, su combinación con piedra blanca de Torrubia acentuaba el contraste frente al que producía el mármol frente a la piedra berroqueña en la propuesta del maestro mayor. Añadía también bronce en capiteles y basas ${ }^{47}$. También parece más suntuosa su propuesta para el presbiterio donde iba colocada la urna del santo, que incorporaba mármoles y jaspes, con mayor colorido, por tanto, que el mármol blanco y negro de Portugal de Gómez de Mora; y el orden dórico de éste era ahora compuesto. Torre dio pocos detalles sobre el alzado exterior de la nueva capilla, y tan solo sabemos que incluía estatuas y tejado de pizarra para el chapitel ${ }^{48}$.

Comentaremos brevemente las opiniones de los maestros que habían concurrido a dar trazas y alguno más ante ciertos aspectos de la traza escogida ${ }^{49}$. Se presentaron el 20 de mayo y en ellas se observan actitudes contrapuestas. Gómez de Mora, apartado de lo que consideraría su competencia, dio un parecer poco complaciente-apoyado en parte por cuatro maestros de obras-, enfrentado en varios aspectos trascendentes a Torre y Bautista, quedando más independiente fray Lorenzo.

Era opinión del maestro mayor, respetada en muchos puntos por los demás maestros, que no se destrabaran las paredes de la iglesia, y que se podía prescindir de la media naranja por no tener crucero. Prefería el orden dórico, muy adecuado para la piedra y el jaspe, porque el corintio o compuesto implicaba hacer adornos en basas, capiteles y follajes de bronce que costarían tiempo y dinero. La obra tenía que ser de albañilería, dejando la cantería sólo para portadas, cornisas, fajas, compartimientos y adornos. El solado, gradas, chapado de portadas a los lados del presbiterio ${ }^{50}$, y banco del retablo habían de ser de mármol de San Pablo con embutidos de jaspe de Espeja. Recomendaba que se hicieran pinturas de la vida y milagros de San Isidro con molduras o tarjetas de mármol negro en los campos de la arquitectura, y el resto de la superficie se pintara de oro y colores. Se debía dividir la obra según especialidades, con condiciones individuales para cada una, dándolas a toda costa, y, si por devoción

46 Nada se dice de una reforma de la capilla mayor, que no debía entrar en la obra. Es posible que esta reforma adicional la propusiera el Rey, sus ministros o los regidores.

47 Desconocemos la materia de Gómez de Mora para las basas, aunque posiblemente sería de mármol de San Pablo como los capiteles. Sin embargo, los fustes eran de piedra berroqueña, sin contrastar con los entrepaños. Pedro de la Torre había dispuesto materiales más caros en su proyecto para la terminación del Ochavo de la catedral toledana de 1639, junto al hermano Bautista, donde abundaba el bronce y combinaban mármol negro y blanco -impuesto por lo construido antes por Monegro- y jaspe rojizo. El concepto visual era el contrario: arquitrabe y cornisa se harían en mármol blanco y el friso en negro.

48 Como veremos más adelante, tenía columnas, orden dórico y piedra berroqueña; Gómez de Mora el mismo orden, pero pilastras y ladrillo, más barato.

49 A.V., A.S.A., 2-283-5. Citado por TOVAR, Arquitectura madrileña..., op. cit., pp. 131-132, quien reprodujo solo un extracto de las declaraciones de Bautista y Torre, la recomendación de Gómez de Mora y fray Lorenzo de que se usara el orden dórico - corintio en el agustino, en realidad- y que intervinieron otros maestros, entre los que citó a Jerónimo Lázaro y Jerónimo Fernández.

50 Serían para acceder a un camarín, novedad respecto a Carbonel y Gómez de Mora, aunque éste incluía una sacristía posiblemente con transparente en su capilla de 1629 y seguro este elemento en su capilla mayor de San Andrés y San Isidro. 
se ofrecieran materiales o su traída, el contratista tendría obligación de recibirlos a los precios corrientes en Madrid. Un alarife elegido por la Villa asistiría para reconocer que los materiales fueran de la calidad conveniente, y pedía que se hiciera un modelo de dos varas de largo para ver las partes y colores de piedras ${ }^{51}$.

Fray Lorenzo de San Nicolás opinó que las pilastras y traspilastras, o bien columnas, se hicieran de mármol de Toledo con sus basas y capiteles de alabastro de Torrubia y de orden corintio, y si hubiera otro encima, compuesto, y lo restante de ladrillo. En cuanto a lo demás seguía a Gómez de Mora, salvo en que fuera un maestro ajenoal encargado quien recibiera los materiales ${ }^{52}$. El hermano Bautista afirmó que se podía edificar la capilla sin derribar la iglesia por ser independiente, y en lo demás se remitía a Gómez de Mora, a excepción del orden y los materiales, que debían ser los propuestos por la traza elegida, por ser "obra tan suntuaria en la Corte" 53 .

\footnotetext{
51 "Juan Gómez de Mora: Que la obra de San Ysidro se aga en quanto a la yglesia sin destravar sus paredes redificándola haciendo su bóveda, y que tanbién se puede hazer media naranxa si conbiniere, pero por no tener crucero, se podría excusar conservando la forma de yglesia que oy tiene. -Que en quanto a la orden de la capilla yglesia se a de guardar la orden dórica por ser una de las cinco más pertenecientes a cosas de piedra y jaspe, porque haciéndose de la orden corintia o conpósita obligarán a hazer muchos adornos, basas, capiteles y follaxes de bronce, que esto sería de mucho gasto y de mucho tiempo. -Que el todo desta obra a de ser de albañilería conforme a su parezer hechando por la parte de afuera portadas de cantería y otros adornos de puertas, cornissas, faxas y compartimientos que hagan labor y hermosura con la albañilería. -Que por la parte de adentro se aga el solado, gradas, chapado al alto que paresciere portadas a los lados del presviterio, banco del retablo de mármol de San Pablo con algunos embutidos de xaspe de Espeja, y que en los campos de la arquitetura desta capilla se puedan poner pinturas de la vida y milagros del santo con molduras o tarjetas de mármol de San Pablo, y que lo demás sea de albañilería y yesería, para que se pueda pintar de oro y colores, por ser obra que a de parecer bien de manos, gasto y de menos tiempo, y que la media naranja que esta misma orden dé riqueza en las faxas, lunetas y requadros. -En quanto a lo obrado le pareze se dé a maestros de entera satisfacción conforme sus facultades, y a estos se les dé a precios a toda costa, con adbertencia que si algún deboto o debotos ofrecieren al santo algunos materiales o el traerlos en la obligación el maestro tenga obligación de rescivirlos a los prescios ordinarios que corrieren en esta Villa, pagándolo de contado o descontárselo de lo que ubiere de aver. -Para esto mandará la Billa que asista de ordinario uno de los alarifes de quien se tenga entera satisfazión para reconocer los materiales para que sean de la calidad y bondad que conviene. -Para la execución desta obra mientras se abren los cimientos y se macizan se aga un modelo del largo de dos varas para que en él se bean obradas todas sus partes, colores de piedras de que se a de executar. -Que se agan condiciones para que cada parte de la que se encargare al maestro o mastros unos de cantería y otros de albañilería, otros de las cosas de mármol y madera. -Que con esto se toma el camino más usado y más perteneciente para ver en breve tiempo acavada la obra, y lo firmó. Joan Gómez de Mora” (A.V., A.S.A., 2-283-5).

52 "El padre fray Lorenço de San Nicolás: Que en quanto al ornato de arquitectura, es su parezer que lo que toca a pilastras y traspilastras o colunas en la parte que las ubiere sean de mármol de Toledo con sus basas y chapiteles de alabastro de Torrubia, y la orden corintia, y si encima deste ubiere otra, sea la compósita con todos los ornatos de las piedras dichas, y los cuerpos de todas las partes sean de ladrillo, y en la parte esterior de afuera se rremite y en todo lo demás a lo que a dicho Juan Gómez de Mora, ecepto que en quanto administrar la obra ponga maestro que resciva los materiales y la aga de manos, y lo firmó. Fray Laurencio de San Nicolás" (A.V., A.S.A., 2-283-5).

53 "El hermano Francisco Bauptista: Dijo que en quanto a edificar la capilla sin el derrivo de la yglesia se puede hazer muy bien por ser cuerpo separado del de la yglesia, viendo que toca el modo de administrar esta obra a maestros con prescios se conforma en todo lo dicho por el dicho Juan Gómez de Mora, sólo en la materia de que se a de fabricar la capilla, según la traça elejida es de parezer se guarde el orden conpuesto que está en sus cortes y alçados, siendo por de dentro pilastras, traspilastras y colunas de mármol de Toledo, con vasas y capiteles de bronce, y todos los demás adornos de la traça pide por ser esta obra tan suntuaria en la Corte y ninguna más, y lo firmó. Francisco Baptista" (A.V., A.S.A., 2-283-5).
} 
Siguieron los pareceres de los cuatro alarifes de la Villa, que admitieron en general las propuestas de Gómez de Mora con algunas precisiones. Jerónimo Fernández Hurtado dijo que el exterior tenía que ser de piedra berroqueña para soportar mejor las inclemencias del tiempo, y el interior de orden dórico, para evitar problemas de roturas de follaje y que se acumulara el polvo y las telarañas ${ }^{54}$. Miguel del Valle y Aguilar prefería que la nave de la iglesia quedara como estaba, por ser fábrica buena, y que se adornara de albañilería con pilastras y traspilastras, fajas, cornisamentos y bóvedas de yesería, en cambio, convenía derribar la capilla mayor para darle el mayor espacio posible, adornándola con pilastras o columnas y entablamentos de mármol de San Pablo con embutidos de jaspes de Tortosa en las superficies, media naranja de yesería con sus fajas, lunetas y recuadros con pintura que imitara los pies derechos, con orden dórico por el interior y exterior, y la obra contratada a toda costa ${ }^{55}$. Cristóbal Colomo coincidía con éste en el modo de remate y en dar los precios a toda costa salvo en pilastras y traspilastras de mármol de San Pablo y capiteles y basas de bronce ${ }^{56}$. Jerónimo Lázaro repitió esto último, y añadió que el interior tenía que ser de orden corintio compuesto y el exterior dórico todo de piedra berroqueña (basas, capiteles, portadas) y los intervalos de albañilería ${ }^{57}$.

Pedro de la Torre ejerció su turno de réplica: se conformaba con no deshacer la iglesia parroquial, sino solamente la pared inmediata a la capilla por ser necesario al sacar sus cimientos. Especificó que el exterior sería de piedra berroqueña con colum-

\footnotetext{
54 "Gerónimo Fernández: Dixo que en quanto a todo el ornato de arquitectura en lo esterior si lo ubiere, conbiene sea de piedra berroqueña, porque es materia que se defiende mexor de los infortunios del tiempo, y en el ynterior le pareze todo conbiene sea del orden dórico, porque lo demás de más de ser muy costoso se criarán muchas telarañas y polvo, y es difícil de limpiar, y por limpiarlo quebrar los follaxes y quedará deteriorado, y en todo lo demás para la execución se dé a maestros tales como conbiene, y que sea a toda costa por prescios fixos, y que la Billa ponga quien visite y reconozca la calidad de los materiales y la buena execución, y lo firmó, y se conforma con lo dicho por Juan Gómez de Mora. Gerómimo Fernández Hurtado" (A.V., A.S.A., 2-283-5).

55 "Miguel del Valle y Aguilar: Dijo que es su parezer que por evitar costas y gastos se conserve el cuerpo de la yglesia como al pressente está, respeto de que su fábrica es buena y capaz para poderla adornar y enrriquecerla con sus bóbedas de yesería, pilastras y traspilastras, faxas y cornisamentos, y en quanto a la capilla mayor se derrive la parte que está hecha, aciéndola más capaz lo que fuera posible, y enrriquecerla su ornato de pilastras o colunas si las ubiere, y cornisamentos de mármol de San Pablo, embutidos con xaspes de Tortosa en todas las partes de los planizios que convenga y aya lugar, y en la media naranja sea de yesería con sus faxas, lunetas y rrequadros colorido de pintura que ymite a la obra de los pies derechos del cuerpo dello, y que esto se entienda en quanto a la capilla del santo, porque en quanto a la yglesia a de ser de albañilería, y que la orden sea dórica por la parte de adentro y fuera sea como lo a dicho Juan Gómez de Mora, y lo mismo en quanto a que la obra a de ser a toda costa, y lo firmó. Miguel del Valle y Aguilar" (A.V., A.S.A., 2-283-5).

56 "Xristóbal Colomo: Dijo que en quanto a la obra y capilla del señor San Ysidro se rremate al parezer de Juan Gómez de Mora, así en lo fabricado como en dar la obra a toda costa por prescios ecepto en las pilastras y traspilastras que se an...mármol de San Pablo, y los capiteles y basas de bronce, y lo firmó. Xristóbal Colomo" (A.V., A.S.A., 2-283-5).

57 "Gerónimo Láçaro: Dijo que en quanto a la execución de la capilla de San Ysidro es su parezer por la parte de adentro sean las pilastras y traspilastras y colunas y otros adornos pertenecientes para la correspondencia de esta fábrica sean de mármol de San Pablo, y las vasas y capiteles de bronce y de la orden corintia conpósita, por la parte exterior sea de piedra berroqueña de orden dórica, y que se entienda ser todos los extremos como son vasas, capiteles, portadas y demás de piedra berroqueña, y lo demás de albañilería lo que toca a los ynterbalos, y en todo lo demás se conforma con lo dicho por Juan Gómez de Mora, y lo firmó. Gerónimo Lázaro" (A.V., A.S.A., 2-283-5).
} 
nas y adorno dóricos como demostraba la planta e insistió en el contraste de negro y blanco, adornos de bronce y el orden compuesto ${ }^{58}$.

Establecida la unanimidad en cuanto al orden dórico y piedra berroqueña para el exterior, el modo de contratación y en evitar el derribo de las paredes de la iglesia, salvo el muro de la epístola al que Torre no renunció, quedaban con posturas contrapuestas los partidarios del orden dórico para el interior (Gómez de Mora, Hurtado, Valle) frente a los que preferían el compuesto (Torre, Bautista, Lázaro, fray Lorenzo ${ }^{59}$ ). La economía de los materiales fue otro objeto de debate: en cuanto a los soportes, presentaron fray Lorenzo, Valle y Lázaro la opción de columnas, más costosas que las pilastras; fueran unas u otras, serían de mármol de San Pablo ${ }^{60}$. Valle no aconsejaba el friso de mármol de Torrubia, sino de jaspe de Tortosa, como las pilastras. Gómez de Mora opinaría igual, porque propuso para el solado y partes del presbiterio iguales embutidos de jaspe, que no sería de Tortosa sino de Espeja. Casi todos aceptaron las basas y capiteles de bronce, aunque los dos últimos los condicionarían a que fueran dóricos, y el agustino los quería menos caros, de piedra de Torrubia, con entrepaños que no serían de esta piedra sino de austerísimo ladrillo. Gómez de Mora puso sobre la mesa fórmulas baratas como el predominio de albañilería sobre la cantería, pinturas de San Isidro molduradas con tarjetas de mármol de San Pablo en los intervalos, y en lo restante yeserías pintadas de oro y colores, volviendo a simular así materiales finos en las bóvedas, como en 1629, en lo que le apoyaba Valle ${ }^{61}$.

Entre discusiones se llegó al 21 de febrero de 1643, en que se realizaron sonadas ceremonias inaugurales. Valle y Torre abrieron zanjas y cimientos y pusieron cordeles $^{62}$. El 2 de marzo, en Junta con presencia de ambos maestros y Bautista, se resolvió que los cimientos llegaran hasta la piedra de elección y que trajera Torre las condiciones para su pregón. Al día siguiente, estando también Gómez de Mora, se leyeron y discutieron las condiciones y se acordó que se mantuvieran seis de las siete preliminares $\mathrm{y}$, en cuanto a la séptima, se estableció que el rodapié de los cimientos debía tener un pie por dentro y por fuera suficiente para bóveda, haciendo traza. De las diecinueve siguientes no se pusieron impedimentos de la novena a duodécima ni a la decimoséptima; se modificó la octava, estableciendo que los cimientos no serían de guijarro sino piedra de Vallecas con mezcla ordinaria de dos espuertas de cal y

58 "Pedro de la Torre: Dijo que se conforma en quanto a que no se desaga la yglesia de San Andrés, más tan solamente la pared ynmediata a la capilla que se a de hazer de San Ysidro, por ser necesario al sacar los cimientos de la fábrica de la dicha capilla, y por la parte esterior della sea de piedra berroqueña con las colunas como demuestra la planta han de ser dóricas con el demás adorno que le toca, y por la parte de adentro a de ser de mármol de San Pablo y de Torrubia, las pilastras de arcos torales y traspilastras sean de mármol de San Pablo y los interbalos de mármoles de Torrubia, de manera que por regla general sean todos los intervalos de mármol blanco y todos sus extremos de mármol negro de Toledo, haciendo los adornos de bronce que demuestra la traça, y en quanto a la orden se rremite a ella de la misma manera por lo saliendo de ella será necesario hazer nueva traza que corresponda a la materia, y en quanto al dar la obra se dé a toda costa a maestros peritos por prescios, y lo firmó. Pedro de la Torre" (A.V., A.S.A., 2-283-5).

59 El recoleto en un hipotético segundo cuerpo, siendo el primero corintio.

60 Para los dos primeros, Torre, Bautista y Colomo.

61 Éste quería imitar en la media naranja mármol y jaspe.

62 Toda esta documentación inédita que va desde este día hasta el 25 de abril de 1644, en A.V., A.S.A., 2-283-6. 
tres de arena. Se aplazaron los pregones de la décimotercera a la décimosexta, que se tratarían en su momento y según el parecer del maestro mayor, para que se realizara con más acierto lo conveniente, y lo mismo de la décimoctava a la vigésimosexta ${ }^{63}$.

La presencia de Gómez de Mora en este acto no era casual, y ya se declaraba que cuatro condiciones dependerían de su opinión para conseguir un mejor resultado. Además el 14 de marzo se vieron las condiciones para la cimentación, que hizo y firmó tres días antes como maestro mayor de la Villa, sin intervención de Pedro de la Torre. Son muy detalladas y demuestran su conocimiento del oficio. Los cimientos tenían que tener una vara más de profundidad que el suelo holladero de la bóveda y sus entierros, dejándolas en anchura por fuera un pie más que el grueso de las paredes del edificio, columnas y zócalos, porque debía servir de zapata y suela al edificio. Como ya se decía en la objeción a la octava condición, los cimientos serían de piedra blanca de Coslada. Se echarían losas de cantería de piedra berroqueña de un pie de grueso y de largo el ancho de los cimientos y construirían escaleras que bajaran de la capilla a la bóveda, con puertas entre los entierros. Como propuso Gómez de Mora, la obra se daría a toda costa y tendría que admitir el maestro la cal o piedra que se ofreciera de limosna. La forma de las bóvedas se dejaba para cuando estuviera más adelantada la tarea.

Asimismo puso precios, y Miguel del Valle lo hizo también el 9 de marzo, eligiendo la Junta los de su maestro mayor por ser más bajos. Se pusieron a subasta hasta el lunes 23 de marzo, y Pedro de la Torre, que estaba presente, hizo postura por esas cantidades, descontando el dinero y materiales que hubiera recibido por las tres nóminas semanales desde que comenzó, trayendo treinta peones. Concertaría finalmente la obra hasta en cantidad de 10.000 ducados.

El mismo 23 hizo baja Pedro de la Peña, aparejador de las obras reales, ofreciendo fianzas hasta 10.000 ducados. En la junta de ese día, a la que asistieron Gómez de Mora, Bautista, Valle y Torre, se admitió y se mandó avisar para su remate a los dos últimos y once maestros de obras más. El 30 hubo otra baja, ésta de 4.000 ducados, por Cristóbal de Aguilera. Valle trajo otros precios, mandándose pregonar hasta el 8 de abril. La primera piedra de la capilla se pondría con prevenciones elaboradas por Gómez de Mora, y se librarían a Torre, maestro de la obra, 2.000 reales a cuenta para estos efectos. El 16 se le ordenó hacer relación de los derribos y despojos de la obra $^{64}$.

La junta del 21 de abril dio un giro completo a la cuestión, un asunto hasta ahora desconocido. Se hallaron presentes Gómez de Mora, Bautista, Valle y Torre. Se deliberó acerca de la traza de éste, porque se había advertido que para continuarla era imprescindible derribar los pilares de la iglesia de San Andrés, por lo que habría que apearla, lo que supondría un coste considerable. El Rey tendría que revisar las trazas, y se acordó que el corregidor diera cuenta a su representante en la obra, el presidente

63 Por ser la construcción de las bóvedas, interior, sacristía e iglesia parroquial fases posteriores de la obra.

64 Dijo haber dado en veinte y un carros de piedra a once reales y medio por orden de don Miguel de Haro, y otra cantidad al también regidor don Francisco de Luzón. Al día siguiente se ordenó que hubiera un libro de los derribos y se hiciera cargo de ellos a Torre. 
de Castilla don Juan de Chumacero y Carrillo, conde de Guaro. Se ordenó interrumpir la venta de materiales, poniéndolos en el corral de la obrería de la capilla, que Miguel del Valle hiciera relación de los despojos y derribos, que informara un comisario distinto cada semana si se quisiera derribar algo, y se suspendió la designación de dos comisarios perpetuos.

Los responsables municipales quedaban en evidencia ante la opinión pública pues la obra, a cuyo comienzo se había hecho gran fasto, se detenía por un error en el planteamiento, precisamente aquél sobre el que había llamado la atención Gómez de Mora. El maestro mayor, que ya en 1629 había propuesto el derribo de un trozo de la pared de la epístola de la parroquial - del evangelio de la capilla- previo apuntalamiento, había acumulado experiencia suficiente en el conocimiento del templo para intuir que el derribo completo de la pared debía incluir los pilares, con un coste y riesgo excesivos. Aguardaría pacientemente este momento en que el plan del inexperto constructor Pedro de la Torre se viniera abajo, saliendo a la luz la deficiencia técnica de unas trazas elegidas por el soberano, ignorante obviamente de este extremo. Se trata de un episodio más del debate candente en la época, tratado con frecuencia por la historiografía actual, acerca de la capacidad de pintores, ensambladores y maestros de otras especialidades para trazar un edificio a pesar de carecer de los conocimientos técnicos que tenían los maestros de obras. El propio Gómez de Mora había vivido una situación similar en el Panteón con Crescenzi. Viene muy al caso citar el conocido alegato de fray Lorenzo de San Nicolás, participante en los proyectos de la capilla, en su tratado" 65 .

\section{El triunfo de Gómez de Mora en el tercer concurso para capilla (1643)}

El 10 de junio volvieron a juntarse los regidores en las casas del presidente de Castilla, como supervisor real de la obra. Vieron las trazas que los maestros habían hecho para la capilla de San Isidro, y entre todas se eligieron cuatro: de Gómez de Mora,

65 SAN NICOLÁS, Fray Lorenzo de, Arte y vso de Architectvra, Madrid, 1639 (ed. anotada por DÍAZ MORENO, Félix, Madrid, Instituto de Estudios Madrileños, 2008), pp. 472-474: "Gana a un príncipe la voluntad muy de ordinario un pintor, un platero, un escultor, un ensamblador, un entallador, y todos estos entienden la arquitectura en quanto a su ornato exterior, y assí adornan un retablo, una fachada, o la traza de esto, con muy buena traza, y disposición. Y no negaré, que se aventajan en el sacar un papel, a los canteros, y alvañiles, y carpinteros, aunque yo he conocido desta profesión quien se les aventaja, porque como estas trazas consisten en un poco de dibujo, el que desta profesión le aprende házeles muchas ventajas en todo, porque como son diferentes los fines, son diferentes los efetos. Pagados desta corteza los príncipes, a estos architectos dan estas plaças, siendo causa que los palacios, los reynos, y los aprendizes que se crían, reciban notable daño, tal, que si repararan en ello, conocieran lo mucho que tenían que restituir. Hazen daño a los edificios en la poca seguridad con los que edifican sus artífices, por la poca experiencia que deste arte tienen. Hazen daño en el gasto, porque para hazertar en una cosa, la hazen y deshazen muchas veces. Pudiera señalar algunos edificios con hartas pérdidas, originadas deste principio, porque qué tiene que ver la bizarría de una pintura, con la fortaleza de un edificio, qué los cortes de un retablo, con los cortes de cantería, y así haziendo cotejo de lo demás....No consiste este arte (como en el discurso de este libro se puede conocer) tanto en lo teórico dél, como en lo práctico; y assí los príncipes, y personas que nombraren los tales maestros, han de procurar los que saben obrar, y trazar con sus manos aquellas materias que han de exercitar, porque lo teórico o especulativo deste arte, a todos los que tienen moderado ingenio, les es común; y particular a sólo los que le practican o ejecutan". 
Pedro de la Torre, fray Lorenzo de San Nicolás y Alonso Cano. Decidieron llevarlos al soberano para que eligiera una de ellas ${ }^{66}$. El 15 de junio ya había escogido Felipe IV el dibujo de Gómez de Mora; en el reverso lo había anotado y firmado el conde de Puñoenrostro, mayordomo de su majestad y regidor y comisario de la obra. El propio maestro mayor haría las condiciones y precios para su mejor ejecución ${ }^{67}$.

Gómez de Mora se alzaba ganador del concurso, como cabía esperar. Había recuperado sus funciones como maestro mayor de las obras reales en detrimento del aparejador mayor Carbonel, que no tenía ya la protección del valido, retirado de la Corte a principio de 1643. El interés que siempre había tenido la Villa en que se hiciera la capilla por sus trazas y el error de Torre terminaron por convertirle en el único capaz de llevar adelante la tarea. Sorprende sobremanera la aparición en este concurso del nombre de Alonso Cano, en lo que supone su primera y única incursión conocida hasta ahora en el campo de la arquitectura de edificios hasta 1653. Es posible que se hubiera presentado en 1638 y 1642 con algún proyecto, bajo la protección del Conde-duque, pero, ahora, sus posibilidades eran mínimas, dadas las circunstancias en que se convocaba este concurso. Aún asi, fue un espaldarazo a sus aspiraciones como arquitecto en la Corte, porque al parecer hubo gran afluencia de maestros que diseñaron trazas, siendo elegido entre los cuatro finalistas ${ }^{68}$.

66 "En la villa de Madrid a diez días del mes de junio de 1643 se juntaron en casa de su señoría ylustrísima del señor don Joan Chumazero y Carrillo, presidente de Castilla, el dicho señor presidente y los señores don Francisco Arébalo de Zuazo, corregidor, don Xristóbal de Medina y don Francisco Sardaneta y don Luis del Castillo y don Francisco Ygnacio de Trasmiera, todos de la orden de Santiago, regidores desta Villa y comisarios de las obras de la capilla de señor Sant Ysidro. Sobre las trazas. En esta junta se bieron todas las trazas que los maestros de obras han hecho para la obra de la capilla y templo de señor San Ysidro, y entre todas se elejieron quatro, que son una que a hecho Joan Gómez de Mora, y otra de Pedro de la Torre, y otra del padre fray Lorenzo de San Nicolás, recoleto agustino, y otra de Alonso Cano, para que las dichas quatro trazas se lleven a su magestad, que Dios guarde, y para que se sirba de elejir la que se a de executar dellas. Francisco Méndez Testa".

67 "En Madrid a quince de junio del año de mill y seiscientos y quarenta y tres años se juntaron en casa de su señoría ylustrísima del señor don Joan Chumazero y Carrillo, presidente de Castilla, el dicho señor presidente y los señores don Francisco Arébalo de Zuazo, corregidor, don Xristóval de Medina y don Francisco Sardaneta, regidores, cavalleros del horden de Santiago y comisarios de la obra y fábrica de señor San Ysidro. -En esta junta, aviéndose savido que su magestad, que Dios guarde, ha sido servido de elejir la traza que a hecho Joan Gómez de Mora, y que a las espaldas della el señor conde de Puñoenrostro, mayordomo de su magestad y regidor desta Villa y comisario e dicha obra lo tiene así anotado y firmado, se acordó se execute y cumpla lo que su magestad manda, y que la obra se haga y para su mexor execución el dicho Joan Gómez de Mora haga las condiziones y precios a que se podrá hazer cada jénero. Francisco Méndez Testa”.

68 Animado y para olvidar su relativa pérdida de peso en la pintura cortesana al dejar de ser pintor del Conde-duque, optó a las plazas de maestro mayor de la Catedral y el Alcázar toledanos para tener unos ingresos fijos y una posición desde la que poder actuar con más asiduidad en la arquitectura. Pero fue una vez más Gómez de Mora quien le cerró esta vía, al declarar en el informe sobre las capacidades de los aspirantes, de 26 de agosto de 1643 que "Alonsso Cano, pintor grande en esta facultad, traça para todo jénero de retablos y otras obras de ensamblaje y adorno con grande primor...". Silenció conscientemente la facultad de Cano como tracista de edificios para favorecer a su candidato, Felipe Lázaro Goiti, quien a la postre resultó elegido. No faltó a la verdad, pues aparte de su faceta de arquitecto de retablos acreditada en Sevilla, y de otras obras de ensamblaje -referencia probable al monumento de Semana Santa del convento real de San Gil en Madrid, que habría diseñado gracias a la protección de Olivares- aludió a otras obras de adorno, entre las que estaría el alzado para la capilla de San Isidro. 
El 21 de junio de 1643 hubo nueva reunión del Consistorio con el presidente de Castilla, quien dijo que Felipe IV había mandado que la capilla y templo se labrara en la plazuela de la Cebada, por lo que Gómez de Mora tendría que ajustar su planta para que se hiciera en ese sitio. El 7 de julio se vio el diseño ya adaptado al nuevo lugar; se acordó que se ejecutara, que el maestro mayor hiciera las condiciones y precios como se había acordado y entregase la planta para que se fuera ejecutando. Esta vez tomó el monarca un papel más activo, independiente de sus consejeros.

El 20 de noviembre, ya en las salas del ayuntamiento y sin don Juan Chumacero, seguramente por estar encauzada la obra, se mandó pregonar la piedra, cal, arena y agua para los cimientos. E1 24 de febrero de 1644 dispuso el corregidor que se librara dinero al maestro al cargo de la obra, 300 ducados más de los que se le habían dado hasta entonces; así lo dijo también el regidor don Diego de Monroy, que asistía a la obra con Miguel del Valle por orden del presidente de Castilla y del corregidor. El 27 se mandó avisar a Gómez de Mora para hacer precios y condiciones de las zanjas y cimientos, y el 12 de marzo averiguamos que el maestro encargado de la obra era Juan Veloso ${ }^{69}$. La última noticia es del 25 de abril. La construcción se abandonó poco después definitivamente. Se produce otra cesura de un año hasta la siguiente noticia, publicada por Cruz Valdovinos ${ }^{70}$. El 26 de mayo de 1645 pidió Pedro de la Torre satisfacción por las trazas que realizó en 1642, y se resolvió que informaran el regidor don Francisco de Luzón y Juan Gómez de Mora. El 27 de agosto de 1646 se vio otra petición del arquitecto para que se le pagara la asistencia y ocupación en la fábrica de la capilla, con votación de todos los regidores. Don Antonio Frías de Estrada y otros cuatro regidores propusieron que se le dieran 300 ducados por la planta y su trabajo, don Jerónimo Piñón 12 reales por cada día del tiempo que asistió a la obra, lo que supondría unos 700 reales $^{71}$, don Jerónimo Casamate y diez regidores más, 200 ducados en total. Don Francisco Sardaneta había oído decir que se le debía dar más pero se conformaba con los 300 ducados, y que se debía dar satisfacción a los otros tracistas, pero solamente a los que habían sido llamados, como aconsejó Gómez de Mora en su informe.

Fue muy duro don Juan de Tapia, quien había estado al tanto de la obra desde 1635 al menos, y afirmó que Torre no había justificado nada de lo contenido en su petición, al no haber sido nombrado por la Villa para hacer trazas ni ser sobrestante ni intervenir en la obra, sino solamente Gómez de Mora como maestro mayor de las obras de la Villa con salario junto con el veedor y sobrestante, que en estos años fue Jerónimo Fernández. Torre no tenía derecho alguno pues había entrado como muchos otros maestros y religiosos - clara alusión al hermano Bautista y a fray Lorenzo- "que por la vanidad de mostrar sus ingenios en las traças y por la aclamación de la causa piadosa de ser esta obra para San Ysidro obraron sus traças, y los maestros especialmente

69 Otro maestro de obras, Juan de Valdomillos, tenía que recibir 800 reales por una escritura de obligación que había otorgado; no había llegado a los 300 ducados en su labor según declaró Valle.

70 A.V., A.S.A., Libro de Acuerdos, nº 60 (1645-1646). CRUZ VALDOVINOS, "Las etapas...", op. cit., p. 202.

71 Lo que hacen unos dos meses, dato exacto, porque trabajó desde el 21 de febrero hasta el 21 de abril de 1643 . 
por la codicia y conbeniencia de que eligiéndose sus traças fueran elegidos para la granjería de executar la obra". Seguía la explicación de haberse detenido la obra de Gómez de Mora en 1644 "siendo ésta de tal calidad que pareció se avía de hacer de limosna y que pudiesen, y que aviendo subcedido el desvanecerse el intento de averse perdido más de catorze mil ducados que pudieron servir para el culto del santo, no pareze se pueda permitir que quiera Pedro de la Torre y los demás que pretenden se les pague, venir a que se perjudique más el caudal del santo en tiempo que no consta tenga ninguno, por lo que antes debe dar quenta de la introducción que hiço en esta obra de los derribos que resultaron dello del dinero que corriese por su mano". No sabemos el motivo del perjuicio de más de 14.000 ducados que se suponía vendrían en forma de limosnas para edificar la capilla de la plaza de la Cebada. Otros tres regidores pidieron que Tapia tratara con Torre y transigiera en que se apartase de todos los derechos por una cifra no superior a 400 ducados. Don Bernardo de Salas dijo que se buscara el acuerdo con el peticionario para que asistiera a la obra hasta su cese, y que si no se llegaba a un acuerdo, lo tasaran alarifes.

Por el grave contratiempo referido por Tapia ${ }^{72}$, Gómez de Mora vio una vez más frustrados sus planes para la capilla, como ya había ocurrido en 1629 (más el de iglesia en torno a 1636) y los intercalados de Carbonel y Torre (1638 y 1642). En su testamento pidió al Consistorio que le sucediera en su puesto su discípulo José de Villareal, como así sucedió. La cláusula revela quizá la preocupación de Gómez de Mora de que no fuera Carbonel, su sucesor en las obras reales, quien trazara la principal obra municipal, la capilla de San Isidro, sino Villareal, nombrado su sucesor para el puesto de maestro mayor de la Villa, como así sucedió ${ }^{73}$.

\footnotetext{
72 Este regidor, que se mostró tan defensor de Gómez de Mora como crítico con Torre, Bautista, fray Lorenzo y los demás concursantes, además de obviar a Carbonel, fue un ardiente defensor de la pintura (PALOMINO, Antonio, El museo pictórico y escala óptica, Madrid, 1715-1724 (ed. Aguilar, 1947), p. 163) y adquirió en la almoneda del pintor Francisco de Palacios en 1652 un costoso retrato de Alonso de Villegas del Greco (CRUZ YÁBAR, Juan María, "Los bienes de Francisco de Palacios, seguidor de Willem Claesz. Heda", De Arte, 12 (2013), pp. 175-196, espec. pp. 178 y 182), que confirma la relación de estos dos personajes -Villegas había elogiado el Entierro del señor de Orgaz en su "Flos Sanctorum"-. Dos noticias más de Palacios de 1650 y 1651 en CHERRY, Peter, Arte y naturaleza. El Bodegón Español en el Siglo de Oro, Madrid, Fundación de Apoyo al Arte Hispánico, 1999, p. 533. La naturaleza muerta que le fue atribuída en el lote 100 de la subasta de Fernando Durán del 3 de julio de 2013 es en realidad italiana (cfr. la de Carlo Maniere en subasta de Ansorena del 2 de octubre del 2007, $\mathrm{n}^{\circ} 33$ ).

73 Se aprovechó el derrumbamiento del techo de la iglesia de San Andrés para construirla nueva contraorientada (TORMO y MONZÓ, Elías, Las iglesias del antiguo Madrid, Madrid, A. Marzo, 1927, t. I, p. 43), haciendo la capilla de San Isidro con dos cuerpos dispuestos de forma ortogonal hacia la capilla mayor. No es imposible que la idea fuera del propio Felipe IV, como ya hiciera en 1643 al situar el proyecto de Gómez de Mora en la plaza de la Cebada. Villareal, en el interior, fue más cercano a Crescenzi y Carbonel, rivales de su maestro, empleando mármoles de San Pablo, jaspes de Cehegín y bronces, más el orden compuesto de Torre y Bautista. La disposición en planta es menos relevante, aunque el debate se haya centrado en este aspecto, condicionado, como en los proyectos anteriores, por el espacio disponible, y no en el del ornato, el más peculiar.
} 